\title{
Situational Leadership And Emotional Intelligence Contribution \\ To Promote Nursing Leaders Effectiveness
}

\author{
Zakaa Mohamed Ahmed EL Bakshawan \\ Master Degree of Nursing Administration \\ Fouada Mohamed Shaban :Prof. of Nursing Administration, \\ Faculty of Nursing,Tana University
}

Abdelsalam Ahmadi EL-Shaikh: Prof. of Clinical Psychology
Faculty of Arts,Tanta University

Karima Ahmed EL-Sayed: Assistant. Prof. of Nursing Administration,

Faculty of Nursing, Tanta University

\begin{abstract}
Background: Situational leadership demonstrated when the leader chooses behavior style suitable with maturity level of followers. Through emotional intelligence nursing leaders can focus on followers emotions as part of the leadership process. Aim: The aim of the present work is to study situational leadership and emotional intelligence contribution to promote nursing leaders effectiveness.Setting: The study was conducted at Desouqe General Hospital, Faysal Hospital, Tropical Hospital, Chest Hospital and Medical Center affiliated to Ministry of Health. Subjects: Head nurses(25) and their nurses subordinates(180). Tools: Four tools were used including leader effectiveness and adaptability description based on situational leadership, emotional competency profile scales, situational leadership and emotional intelligent knowledge test , and an educational program for nursing leaders about situational leadership and emotional intelligence. Results: Nursing leaders level of knowledge regard situational leadership and all total emotional intelligent competencies improved post program than pre program. Post program nursing leaders participating leadership style has the highest probability of success style. Also the levels of nursing leaders effectiveness was promoted and rater readiness for situational leadership style were improved post program than pre program. Conclusion: nursing leaders at the studied setting need great attention to periodically attend program on situational leadership and emotional intelligence to keep their promotion of leadership effectiveness .Recommendations: Periodic attendance of educational and training programs for nursing leader and nursing staff about various leadership styles, and situational leadership skills and emotional intelligence competencies.
\end{abstract}

Keywords: Situational leadership, emotional intelligence, nursing leaders. 


\section{Introduction}

leadership is an interpersonal process , involves both followers and leaders to direct followers' activities towards the purposeful pursuance of given objectives within a particular situation by means of communication $^{(1)}$.Leadership considered as a social influence process to seek the voluntary participation of subordinates in an effort to reach organizational goals ${ }^{(2)}$. Leadership effectiveness determined by the leader ability to influence followers within a particular situation and social context in a way that induces them to follow, to be modified, and to be directed toward goal achievement ${ }^{(3)}$. As well as to turn own beliefs and visions into reality, through the control and influence they exercise over followers ${ }^{(4)}$. Effectiveness of nursing leaders appear in their ability to act the appropriate leadership style to inspire followers to work together willingly and cooperatively with zeal and confidence and to their greatest potential using appropriate means to achieve common mission and goals ${ }^{(5)}$.

Situational leadership effectiveness needs that a leader has to be appropriate own behavior regarding the commitments and competences of nursing subordinates in every situation . Effective leadership is demonstrated when the leader chooses a behavior that coincides with the maturity or readiness level of followers ${ }^{(6)}$.Effective situational leaders diagnose the situation, identify the leadership style that will be most effective, and then determine whether they can implement the required style.

However situational nursing leader is effective only if can recognizes the needs of nursing staff and change own behavior according to according to their needs (7) . That leaders decide task behavior and/or relationship behavior to act according to follower's maturity levels to lead them toward goal achievement . Task behavior is a directive behaviors, leaders use for goal setting, developing action plans, clarifying roles, showing how, evaluating, establishing timelines, and setting priorities. Relationship behaviors is a supportive behaviors leaders use for praising , organizational and individual information sharing, problem solving, asking for input, and providing rationale . Effective situational leaders apply both task and relationship behavior through four leadership styles (telling, selling, participating and delegating)to match from them with the followers maturity level ${ }^{(7,8)}$. Maturity or readiness level is the degree of followers state of being ready or 
prepared for action, use information and communication , having good will, handiness, promptitude, alertness, cleverness and zeal to act gladly in arriving mission ${ }^{(7,8)}$.

Telling style is directing style, leaders focus on the task and not on the relationship with the employee. Leaders used to deal with subordinates who are neither competent nor confident and unable to achieve the task. Leader use to define roles and tells them how to do their jobs especially followers lack both skills and confidence to perform own assigned duties ${ }^{(7,8)}$.Selling style is both directive and supportive style. Leaders used when followers have some competence of the task but lack full capability to complete it, that they are motivated but currently lack the appropriate skills. Leaders identify roles and give followers an opportunity to ask for direction and clarification also encourage subordinates to complete tasks.

Participating style is a supporting style leaders use to increase motivation when employees have high competence and commitment to achieve, leader share ideas and discuss what to do and let the employee be the one that decide how to complete the task. Delegating style leaders use it when followers are expert self-motivated, and have commitment to achieve the task. So followers able and willing to accomplish goals by themselves with little or No direction or support.

That leaders delegate the task and let followers complete it .

Emotional intelligence has vital role for leadership effectiveness. Through emotional intelligence nursing leaders focus on followers emotions as part of the leadership process . Emotional intelligence was defined as the ability to perceive , appraise, and express emotions appropriately. Effective nursing leaders through emotional intelligence consistently communicate appropriately with others, recognize others emotional needs and own, and create positive relationships based on mutual safety, trust, and confidence $^{(9,10)}$.

So developing emotional intelligence competencies establishes capabilities for functioning within the situational leadership effectively. Consequently nursing leaders must develop the following emotional intelligence competencies(emotional literacy, selfesteem/self-regard, self management, self motivation , change resilience, interpersonal relations and integration of head and heart) that will aid in exercising situational leadership effectively ${ }^{(10-12)}$. 
The first competence is emotional literacy means awareness and understanding of subjects (own and other people's) emotions ,second competence self-esteem means ability to have the courage to stand by one's values in the face of opposition, as well as the ability to admit to mistakes in public and even possibly laugh at oneself, if and when appropriate, third competence self-management means ability to manage stress and harness energy to create wellness and healthy balance between body, mind and soul without neglecting on to gratify another forth competence is selfmotivation means ability to create a challenging vision and stretching goals; to remain focused and remain committed to cause ; and to take responsibility for one's successes and failures.

Fifth competence is change resilience means ability to remain flexible and open to new ideas and people, advocating the imperative for change and innovation when appropriate, with due concern and consideration for the emotional impact of change on people, Six competence is interpersonal relations means intuitive understanding of , and deep level of caring and compassion for people; a real concern for subjects well-being, growth and development, and joy and recognition for subjects success and the last integration of 'head and heart' means ability to make decisions and solve problems with due consideration of both facts and feelings and with the commitment to create winwin solutions that serve both the goals and the relationships concerned.

Apparently nursing leaders who utilize emotional intelligence be able to effectively develop goals and create ways to achieve those goals, as well as effectively communicate a newly created vision in a way that motivate nurses to share the vision. As the utilization of emotional intelligence allowed nursing leaders to assess and manage others' emotions when making decisions, when assisting followers in identifying and expressing emotions, and when altering the feelings of followers in more productive ways to transform the $\operatorname{organization}^{(9,10)}$.

Situational leadership and emotional intelligence educational program for nursing leaders may help them to be more effective through managing different highly charged emotional situations. The modern demands of nursing drew the skills of emotional intelligence to meet the needs of directed patient care and cooperative negotiations with multidisciplinary team (9). 


\section{Aim Of The Study}

The aim of the present work is to study situational leadership and emotional intelligence contribution to promote nursing leaders effectiveness.

\section{Research hypothesis}

1-The educational program for situational leadership and emotional intelligence can improve nursing leaders knowledge.

2- Nursing leaders improvement of knowledge about situational leadership and emotional intelligence can promote their level of leadership effectiveness.

\section{Materials and Method}

-Materials

\section{Study Design}

A quasi-experimental research design was used to achieve the aim of present research.

\section{Setting}

The study was conducted at Desouqe General Hospital,Faysal Hospital,Tropical Hospital, Chest Hospital and Medical Center affiliated to Ministry of Health

\section{Subjects}

- Professional head nurses leaders (25) who have actual leadership role were included in the study. Head nurses leaders working at Desouqe General Hospital were (16) . Faysal Hospital were
(4) , Tropical Hospital were (3) . one head nurse Chest Hospital and one working at the Medical Center.

- All (180) nurses subordinates were included in the study. Each of the (25) nursing leaders subject had at least (2-5) subordinates subject. Nurses subordinates subject working at Desouqe General Hospital were 100, Faysal Hospital were 24, Tropical Hospital were 27, Chest Hospital were 11 and Medical Center were 18 nurses.

Tools: To achieve the aim of the study four tools were utilized

Tool(I):The leader effectiveness and adaptability description based on situational leadership, it consisted of two parts :-

Part one This part included items related to characteristics of the subjects such as age, marital status, work unit, years of experience, leadership years of experience , qualification and previous attendance of leadership programs.

Part two This part included leader effectiveness and adaptability description questionnaire developed by Paul and Kenneth $(1988)^{(13)}$ then reused by Léo and Eduardo (2006) ${ }^{(14)}$. Two forms for the questionnaire were used, one for leader and the other for rater. 
-Lead-self Scale is the leader form to determine what leadership style they perceive themselves to follow. The leaders were asked how would they will act in specific twelve situations to identify their leadership style.

-Lead-other form is the subordinate rater form to identify their perceptions for their leader's style of leadership .

The forms of leader and rater contained the same twelve situations written from different perspectives. Every situation has four answers to choose to determine leaders adaptability style as well as the level of leader effectiveness indicated by subordinate readiness to do tasks.

Scoring for leaders leadership adaptability style

Leaders leadership adaptability style were designed in a way that there is no "right" or "wrong" answers, only different ways of acting in certain situations to determine the leader leadership style.Each situation has four responses(A,B,C and D ), each response correspond to specific leadership style to choose among them.

The leadership style and effectiveness scoring key represents as follow:

- The style with highest probability of success scored with $(+2)$.

- The second best alternative is scored $(+1)$.
- The third alternative is scored (-1).

- The style with lowest probability scored $(-2)$.

Percentages of each style was calculated to determine dominant style which has highest frequency percent and second styles has at least $16.7 \%$.

Leadership effectiveness scoring is ranging as follow:

-High leader effectiveness (range +13 $+24)$.

-Moderate leader effectiveness (range +1 +12 ).

-Low leader effectiveness (range -12 -0).

-Very low leader effectiveness (range -24 $-13)$.

Tool (II): Emotional Competency Profile Scales

The emotional competency profile scales was developed by Wolmarans and Greeff $(2001)^{(15)}$ and reused by Palmer and Jansen (2004) ${ }^{(16)}$.It consists of leader and rater forms to determine the emotional intelligence of nursing leaders subjects.

-The leader's form to be completed by leaders to determine their own level of emotional intelligence .The rater's form includes the same questionnaire to be completed by subordinates regarding their leader's emotional intelligence.

The emotional competency profile scale contains 46 items divided into seven 
competencies subscales emotional literacy (6 items), self-esteem/self-regard(6 items), self-management (6 items), selfmotivation(6 items), change resilience(7 items), interpersonal relations (9 items), and the integration of head and heart(6 items) .

Scoring of emotional competency profile scales(leader and rater forms) are measured on a seven-point Likert Scales ranging from 1-7 (never, hardly ever , seldom, do not use rating, occasionally, most of the time and always). The higher the mean score on the current behavior scale, the higher the level of emotional intelligence demonstrated by the leaders.

Levels of emotional intelligence:-

- High level $=>75 \%$.

- Moderate level $=60 \%-75 \%$.

-Low level $=<60 \%$.The high and moderate levels mean nursing leaders have adequate emotional intelligence while low level means nursing leaders have

inadequate emotional intelligence.

Tool (III) Situational Leadership and Emotional Intelligent Knowledge Test.

This tool developed by the researcher based on recent related literature ${ }^{(7,8,9,11)}$ to collect data about nursing leaders' knowledge for situational leadership and emotional intelligence. The questions constructed in the form of either complete from the list ,true or false and multiple choice questions. The test composed of fifty questions .

Scoring system of the knowledge test

The total score for knowledge test was 100 score ,the correct answer take two points and incorrect answer take zero.

Levels of knowledge on situational leadership and emotionally intelligent:

-High level $=>75 \%$.

-Moderate level $=60 \%-75 \%$.

-Low level $=<60$.

The high and moderate levels mean nursing leaders have adequate knowledge but the low level means nursing leaders have inadequate knowledge.

Tool (IV): An Educational Program for Nursing Leaders about Situational Leadership and Emotional Intelligence.

The program developed by the researcher based on the findings of tool (I) Leader effectiveness and adaptability description based on situational leadership, tool (II) :emotional competency profile scales and tool (III) situational leadership and emotional intelligent knowledge test, as well as reviewing of recent relevant literature .At the end of educational program nursing leaders expected to improve their knowledge for both 
emotional intelligence and situational leadership

\section{Method}

1-Official permission to carry out the study was obtained from responsible authorities of study setting .

2-Tool(I)Leader effectiveness adaptability description questionnaire ( leader and rater forms) and tool ( II ) emotional competency profiler questionnaire (leader and rater form ) were translated into Arabic language . The translated tools tested by nine expertise in nursing services administration and in psychology to evaluate the translated tools items in relation to its relevance and appropriateness on a five points scale ranging from 1-5 as follows:-

$1=$ Not very relevant $2=$ Not relevant $3=$ Usual $\quad 4=$ Relevant

$5=$ Very relevant

An evidence of content validity was then calculated .The content validity of the study tools were for tool ( I ) ranged from $82.5 \%$ to $87.5 \%$, for tool(II) ranged from $82.5 \%$ to $87.5 \%$, and for tool(III) ranged from $84 \%$ to $100 \%$.The content validity scored $80 \%$ or more is considered have accepted content validity 3-Pilot study conducted on five leaders and six subordinates to ensure the clarity and identify obstacles during data collection ( pilot study sample did not involved in study sample).

4-Modifications were done based on the results of pilot study sample and jury opinion of nine expertise.

5-Tool(I)The leader effectiveness and adaptability description based on situational leadership, lead - self scale were administered to studied nursing leaders to determine what leadership style they perceive themselves to have pre program. And the form lead -others were administered to their raters to determine their perception on their leader's leadership style .

6-Tool (II): The emotional competency profile scales leader form were administered to studied nursing leaders and rater form were administered to studied nursing rater to determine the emotional intelligence of nursing leaders subject.

7- Nursing leaders situational leadership and emotional intelligent knowledge was tested by tool(III) pre and post program.

8-Responding time for tool(I),tool(II)and for tool(III)half hour. The researcher was present during data collection to provide guidance and clarification. 
9-An educational program for nursing leaders for situational leadership and emotionally intelligent knowledge was designed and translated into Arabic language based on the collected data and literature review .

10 -The program was implemented by the researcher; it encompassed ten hours duration divided into five session each one two hours repeated for five times, and administered according the suitable and agreed time for nursing leaders.

11- Duration of data collection lasted seven months began from the last week in October 2010 till the third week in May 2011.

Program of this study classified into four phases as follows:-

phase 1:Assessment

Nursing leaders situational leadership and emotional intelligence levels were assessed using tools (I,II) pre and post program implementation. Then researcher administered situational leadership and emotional intelligent knowledge test tool (III) to assess nursing leaders levels of situational leadership and emotional intelligent knowledge for developing the needed educational program.
Phase 2 Development of the educational program

The constriction of educational program included statement of general and specific objectives ,as well as selection and organization of the program contents were in 5 sessions .

\section{Learning Strategies}

Selection of teaching methods was governed by studying the subject themselves and content of the situational leadership and emotional intelligence program . The methods used in teaching of the program included group discussion and lecture .The teaching aids used in the situational leadership and emotional intelligence program were flip chart and examples from work environment.

Phase 3:Implementation of the program The situational leadership and emotional intelligence program is a theoretical sessions were held in the study setting. The program has ten hours divided into five sessions every session two hours. Activities carried out in the sessions illustrated in the following sheets. The program repeated for 5 times each sessions 5 nursing supervisors. The studied nursing leaders were informed about the general instructional objectives of program of 
each session .The researcher built good relation and gave a simple form of motivation to enhance the leaders participation and more involvement in the program activities.

Phase 4:Evaluation of the program

The situational leadership and emotional intelligence educational program for nursing leaders was evaluated through :

1-Tool (I) demonstrated to nursing leaders and raters pre and post program to assess the change in nursing leaders effectiveness and adaptability act for situational leadership styles.

2- Tool (II) demonstrated to nursing leaders and raters pre and post program to assess nursing leaders change in emotional intelligence levels .

3-Nursing leaders were given a knowledge test tool (III)pre and post program to assess their change in knowledge regarding situational leadership and emotional intelligence

12-Researcher put the educational materials of situational leadership and emotional intelligence program in booklet to be a guide for them and other leaders to improve and practice emotional intelligence and situational leadership.

\section{Statistical analysis}

Results were tabulated and statistical analysis was performed with Statistical Package for Social Sciences(SPSS version 17.0).For quantitative data,the mean and standard deviation were calculated. Comparison between the studied sample(pre program and post program data)was performed using t-test and paired t-test .For qualitative data, the number and percent was calculated .Chi square was used as a test of significance.P-value $\leq 0.05$ were considered statistically significant.

\section{Results}

Results revealed that Table(1)represents characteristics of nursing subjects, leaders and raters. Equal percent $40 \%$ of nursing leaders were in age group less than 30and from 30-35years. High percent $76 \%$ of nursing leaders were married .68\% have less than 10 years of experience and $88 \%$ have more than 5 years of experience as leaders. All nursing leaders have baccalaureate degree and only $20 \%$ of them were attend leadership programs . Half of nursing raters age ranging 3035 and equal $25 \%$ aged less than 30 and more than35. Majority $71.7 \%$ of nursing raters were married and $60.6 \%$ have more than and equal 10 yearsof experience. Majority $92.77 \%$ of nursing raters have 
technical degree education and only $7.22 \%$ have baccalaureate degree.

Table(2)represent differences between nursing leaders levels of knowledge for situational leadership styles pre and post educational program. The table shows statistically significant improvement of nursing leaders levels of knowledge on all situational leadership styles (telling, selling, participating, delegating) post the educational program at $\mathrm{p}<0.05$.

Table (3) represents nursing leaders levels of knowledge for leadership effectiveness aspects pre and post the educational program. The table shows statistically significant improvement of nursing leaders levels of knowledge for leadership effectiveness aspects post program at $p \leq 0.05$ than pre program.

Table (4) Differences between nursing leaders levels for knowledge for emotional intelligence competencies scales pre and post educational program. The table shows that there is a statistically significant improvement of nursing leaders level of knowledge on all emotional intelligence and competencies post the educational program at $\mathrm{p}<0.05$. The nursing leaders high level competencies increased and the low level competency decrease for all type of competencies on emotional intelligence post program.
Figure (1) shows nursing leaders situational leadership and emotionally intelligent knowledge level pre and post program. The nursing leaders high level of situational leadership and emotionally intelligent knowledge doubled, their moderate level decreased and their low level decreased post program than pre program.

Figure (2) Nursing leader effectiveness and adaptability description data profile illustrate that pre program less than half of nursing leaders behave in participating style followed by selling style and telling style . Post program participating style has the highest responses of nursing leaders to perceive own selves followed by selling style ,delegating style and 1 telling style respectively

Figure(3) shows levels of leaders effectiveness for situational leadership pre and post program among raters. Pre program more than half of raters showed themselves at moderate readiness level which mean moderate effectiveness level for leaders, followed by low readiness and high readiness level respectively. But post program, most raters showed themselves at high readiness level, followed by moderate readiness and low readiness level respectively. 
Table(1) Characteristics of Nursing Subjects (Leaders and raters) $\mathbf{n}=205$

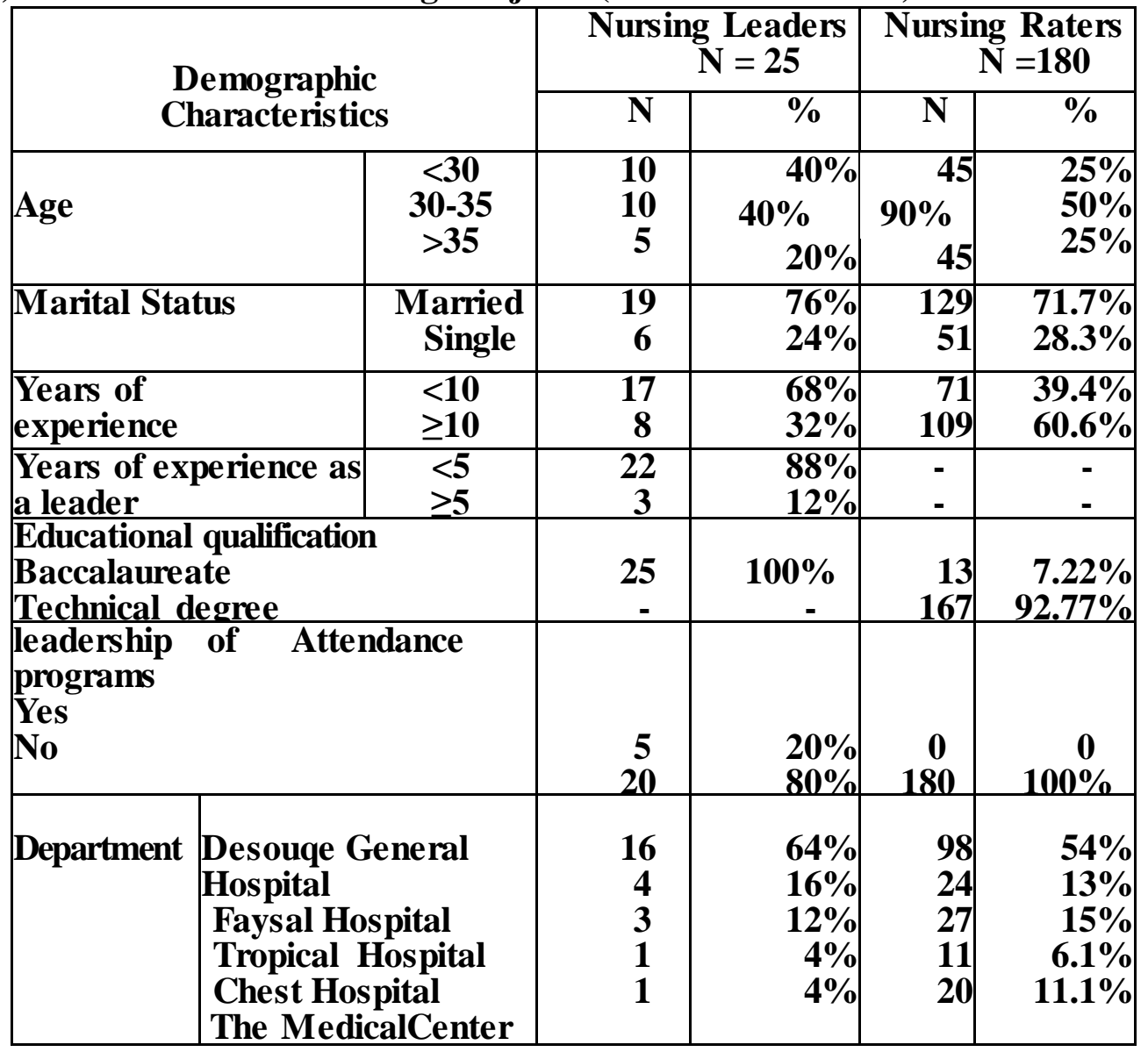

Table(2)Differences between nursing leaders levels of knowledge for situational leadership styles pre and post educational program $n=25$

\begin{tabular}{|c|c|c|c|c|c|c|c|c|c|}
\hline \multirow{3}{*}{$\begin{array}{l}\text { Situational } \\
\text { leadership } \\
\text { styles }\end{array}$} & \multirow{3}{*}{$\begin{array}{l}\text { Pro- } \\
\text { gram }\end{array}$} & \multicolumn{6}{|c|}{ Levels of nursing leaders } & \multicolumn{2}{|c|}{ Chi square } \\
\hline & & \multicolumn{2}{|c|}{ High } & \multicolumn{2}{|c|}{ Moderate } & \multicolumn{2}{|c|}{ Low } & \multirow{2}{*}{$\mathrm{X}^{2}$} & \multirow{2}{*}{$\begin{array}{c}\text { p- } \\
\text { value }\end{array}$} \\
\hline & & $\mathbf{N}$ & $\%$ & $\mathbf{N}$ & $\%$ & $\mathbf{N}$ & $\%$ & & \\
\hline \multirow{2}{*}{ Telling } & pre & 5 & 20 & 10 & 40 & 10 & 40 & \multirow[b]{2}{*}{3.02} & \multirow[b]{2}{*}{$0.05 *$} \\
\hline & post & 10 & 40 & 10 & 40 & 5 & 20 & & \\
\hline \multirow{2}{*}{ Selling } & pre & 3 & 12 & 10 & 40 & 12 & 48 & \multirow[b]{2}{*}{3.09} & \multirow[b]{2}{*}{$\mathbf{0 . 0 5 *}$} \\
\hline & post & 12 & 48 & 8 & 32 & 5 & 20 & & \\
\hline \multirow{2}{*}{ Participating } & pre & 5 & 20 & 12 & 48 & 8 & 32 & \multirow[b]{2}{*}{3.00} & \multirow[b]{2}{*}{$0.05 *$} \\
\hline & post & 20 & 80 & 2 & 8 & 3 & 12 & & \\
\hline \multirow{2}{*}{ Delegating } & pre & 4 & 16 & 10 & 40 & 11 & 44 & \multirow[b]{2}{*}{3.01} & \multirow[b]{2}{*}{$0.05 *$} \\
\hline & post & 18 & 72 & 5 & 20 & 2 & 8 & & \\
\hline
\end{tabular}

*significance at $\mathbf{p}<0.05$ 
Table(3) Nursing leaders levels of knowledge for leadership effectiveness aspects pre and post the educational program

\begin{tabular}{|c|c|c|c|c|c|c|c|c|c|}
\hline \multirow{3}{*}{$\begin{array}{l}\text { leadership } \\
\text { effectiveness } \\
\text { aspects }\end{array}$} & \multirow{3}{*}{$\begin{array}{c}\text { Progra } \\
\text { m }\end{array}$} & \multicolumn{6}{|c|}{$\begin{array}{c}\text { Levels of nursing leaders } \\
\text { knowledge leadership } \\
\text { effectiveness aspects }\end{array}$} & \multirow{2}{*}{\multicolumn{2}{|c|}{ Chi-square }} \\
\hline & & \multicolumn{2}{|c|}{$\begin{array}{c}\text { High } \\
100 \geq 75\end{array}$} & \multicolumn{2}{|c|}{$\begin{array}{c}\text { Modera } \\
\text { te } \\
75 \geq 60\end{array}$} & \multicolumn{2}{|c|}{$\begin{array}{c}\text { Low } \\
60 \geq 0\end{array}$} & & \\
\hline & & $\mathbf{N}$ & $\%$ & $\mathbf{N}$ & $\%$ & $\mathbf{N}$ & $\%$ & $\mathrm{X}^{2}$ & p-value \\
\hline \multirow{2}{*}{$\begin{array}{l}\text { Leadership } \\
\text { effectiveness } \\
\text { aspects }\end{array}$} & pre & 2 & 8 & 5 & 20 & 18 & 72 & \multirow[b]{2}{*}{4.01} & \multirow[b]{2}{*}{$0.05^{*}$} \\
\hline & post & 17 & 68 & 3 & 12 & 5 & 20 & & \\
\hline \multirow{2}{*}{ Total } & pre & 2 & 8 & 5 & 20 & 18 & 72 & \multirow[b]{2}{*}{4.22} & \multirow[b]{2}{*}{$0.05^{*}$} \\
\hline & post & 17 & 68 & 3 & 12 & 5 & 20 & & \\
\hline
\end{tabular}

* significance at $\mathbf{p} \leq \mathbf{0 . 0 5}$

Table (4) Differences between nursing leaders levels of knowledge for emotional intelligence competencies scales pre and post educational program $\mathrm{N}=\mathbf{2 5}$

\begin{tabular}{|c|c|c|c|c|c|c|c|c|c|}
\hline \multirow{3}{*}{$\begin{array}{c}\text { Scale s of } \\
\text { emotional } \\
\text { intelligence } \\
\text { competencies }\end{array}$} & \multirow{3}{*}{$\begin{array}{l}\text { Pro- } \\
\text { gram }\end{array}$} & \multicolumn{6}{|c|}{$\begin{array}{l}\text { Levels of nurs ing leaders } \\
\text { knowledge }\end{array}$} & \multirow{2}{*}{\multicolumn{2}{|c|}{ Chi-s quare }} \\
\hline & & \multicolumn{2}{|c|}{ High } & \multicolumn{2}{|c|}{ Moderate } & \multicolumn{2}{|c|}{ Low } & & \\
\hline & & $\mathbf{N}$ & $\%$ & $\mathbf{N}$ & $\%$ & $\mathbf{N}$ & $\%$ & $\mathrm{X} 2$ & p-value \\
\hline \multirow{2}{*}{$\begin{array}{l}\text { Emotional } \\
\text { literacy }\end{array}$} & Pre & $\mathbf{0}$ & $\mathbf{0}$ & 10 & 40 & 15 & 60 & \multirow[b]{2}{*}{3.4} & \multirow[b]{2}{*}{$0.05 *$} \\
\hline & Post & 10 & 40 & 12 & 48 & 3 & 12 & & \\
\hline \multirow[b]{2}{*}{ Self-esteem } & Pre & 2 & 8 & 12 & 48 & 11 & 44 & \multirow[b]{2}{*}{2.4} & \multirow[b]{2}{*}{$0.05 *$} \\
\hline & Post & 12 & 48 & 11 & 44 & 2 & 8 & & \\
\hline \multirow{2}{*}{$\begin{array}{l}\text { Self } \\
\text { management }\end{array}$} & Pre & 2 & 8 & 15 & 60 & 8 & 32 & \multirow[b]{2}{*}{3.9} & \multirow[b]{2}{*}{$0.05^{*}$} \\
\hline & Post & 11 & 44 & 11 & 44 & 3 & 12 & & \\
\hline \multirow{2}{*}{$\begin{array}{l}\text { Self } \\
\text { motivation }\end{array}$} & Pre & 1 & 4 & 15 & 60 & 9 & 36 & \multirow[b]{2}{*}{4.1} & \multirow[b]{2}{*}{$0.05 *$} \\
\hline & Post & 10 & 40 & 12 & 48 & 3 & 12 & & \\
\hline \multirow{2}{*}{$\begin{array}{l}\text { Change } \\
\text { resilience }\end{array}$} & Pre & 2 & 8 & 8 & 32 & 15 & 60 & \multirow[b]{2}{*}{5.2} & \multirow[b]{2}{*}{$0.05^{*}$} \\
\hline & Post & 13 & 52 & 9 & 36 & 3 & 12 & & \\
\hline \multirow{2}{*}{$\begin{array}{l}\text { Interpersonal } \\
\text { relations } \\
\end{array}$} & Pre & 3 & 12 & 5 & 20 & 17 & 68 & \multirow[b]{2}{*}{4.9} & \multirow[b]{2}{*}{$0.05^{*}$} \\
\hline & Post & 12 & 48 & 9 & 36 & 4 & 16 & & \\
\hline \multirow{2}{*}{\begin{tabular}{|l|} 
Integration of \\
head and heart
\end{tabular}} & Pre & 2 & 8 & 8 & 32 & 15 & 60 & \multirow[b]{2}{*}{4.6} & \multirow[b]{2}{*}{$0.05 *$} \\
\hline & Post & 13 & 52 & 9 & 36 & 3 & 12 & & \\
\hline \multirow[b]{2}{*}{ Total } & Pre & 2 & 8 & 15 & 60 & 8 & 32 & \multirow[b]{2}{*}{4.3} & \multirow[b]{2}{*}{$0.05^{*}$} \\
\hline & Post & 12 & 48 & 8 & 32 & 5 & 20 & & \\
\hline
\end{tabular}

* significance at $\mathbf{p}<0.05$ 


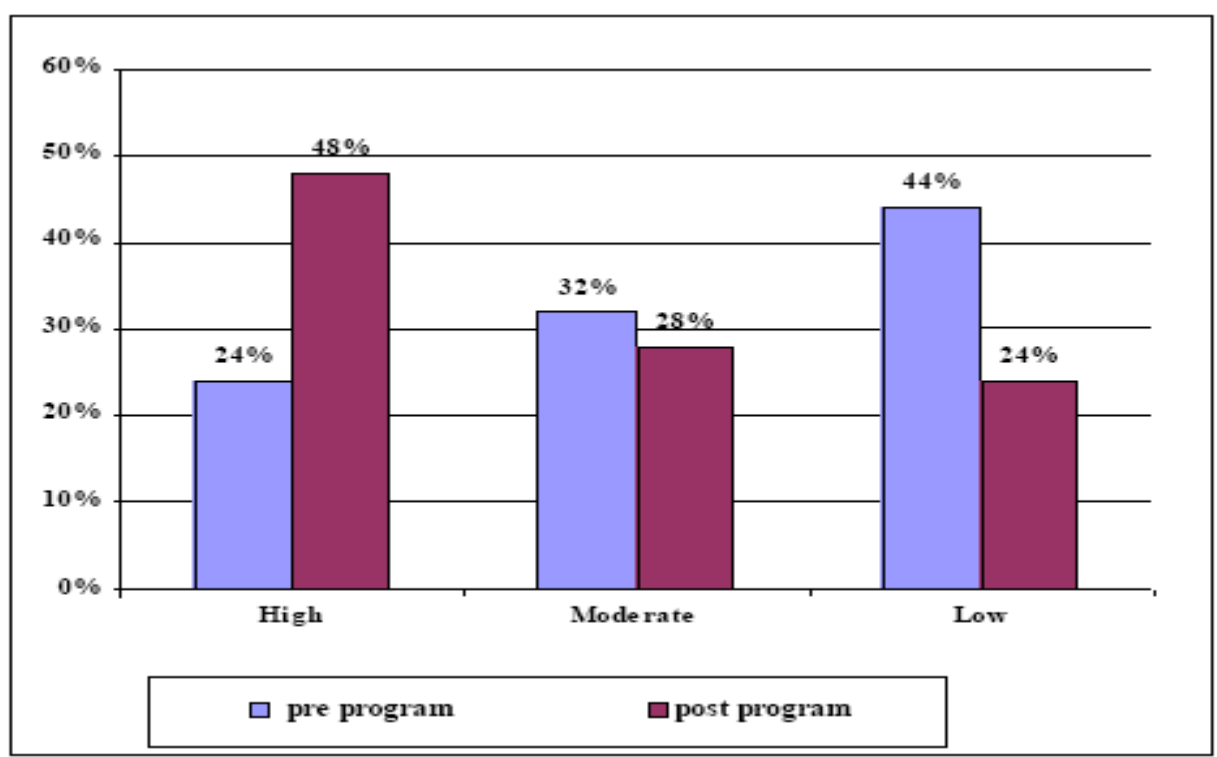

Figure (1) Nursing Leaders Situational Leadership and Emotionally Intelligent knowledge level pre and post program $\mathrm{N}=25$

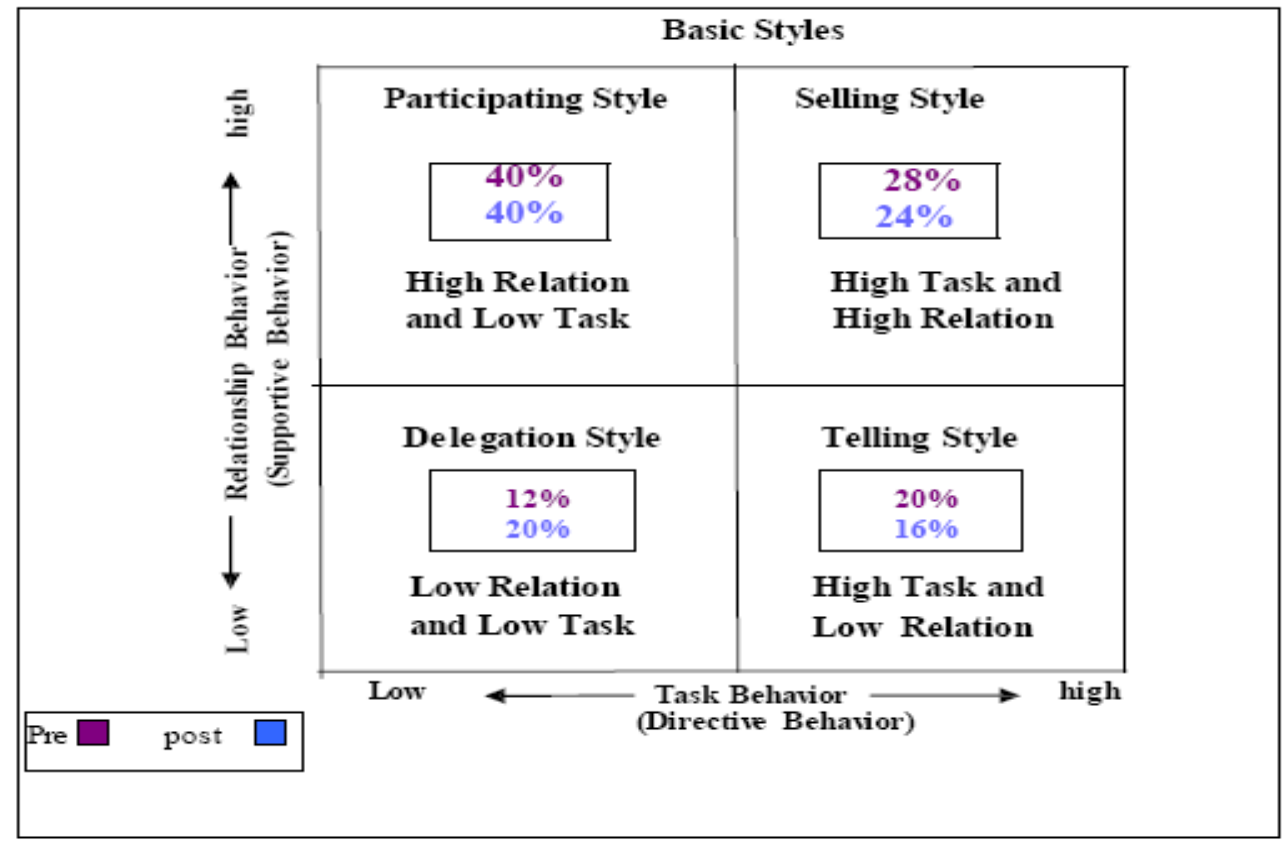

Figure (2)Nursing leader effectiveness and adaptability description data profile $\mathrm{N}=\mathbf{2 5}$ 


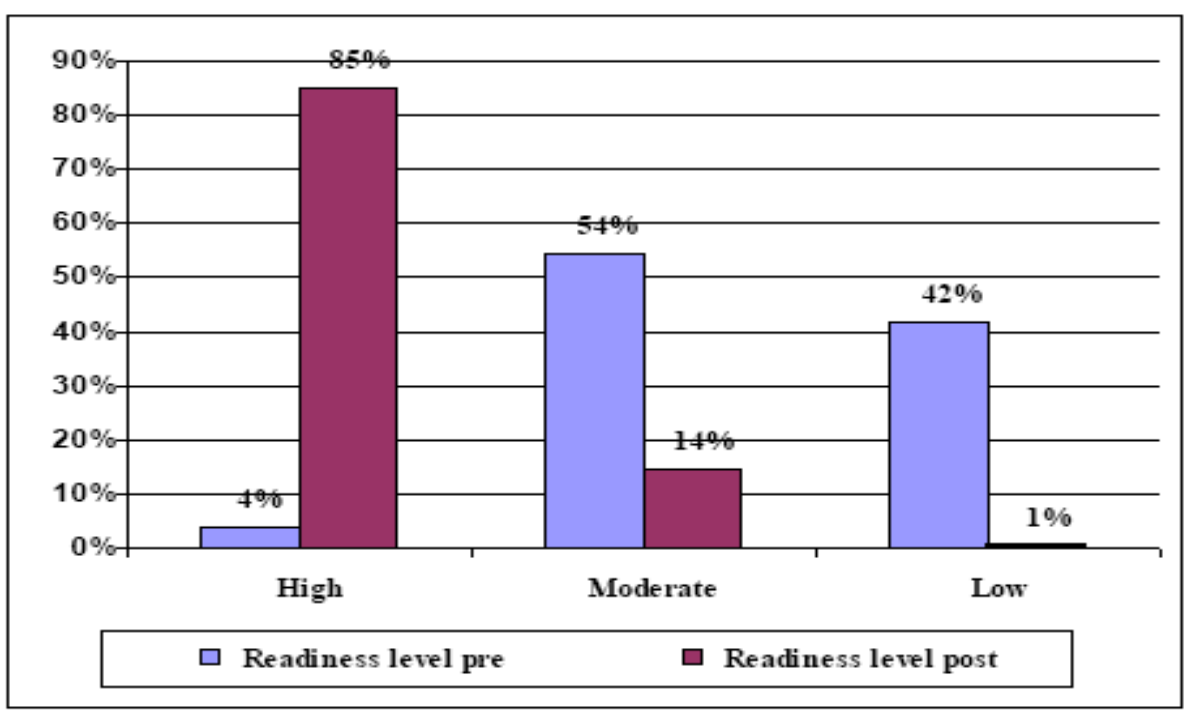

Figure (3) levels of Nursing Leaders Effectiveness for Situational Leadership pre and post program among raters $\mathrm{N}=180$

\section{Discussion}

Situational leaders are able to determine followers needs in different work situations and adopt suitable leadership style to behave to accomplish the intended goal. Emotional competence plays critical role in leadership, whose quintessence lies in putting others on the right path to do their jobs more efficiently. The emotionally intelligent leaders are more apt to engage in necessary needed leadership behaviors such as listening, praising, information sharing, asking for input and providing rationale with in different situations. Effective situational leaders depend on their emotional intelligence competencies when switching from one leadership style to another according work situation and followers needs .

The present study revealed statistical significant improvement in the nursing leaders level of knowledge about situational leadership and emotional intelligence post program . Apparently the nursing program was effective in improving those nursing leaders situational leadership and emotional intelligent knowledge. The fact is that the nursing leaders became knowledgeable for different situational leadership styles and recognize the use of emotional intelligence for changing their leadership style according to their followers readiness .Most probably they know how to use 
situational leadership model to place less or more emphasizes on the task and on relationship with the followers depending on what is needed to get the job done successfully.

$\operatorname{Duggan}(\mathbf{2 0 1 3})^{(17)}$ study about description of leadership effectiveness and adaptability, supported results of the present study and reported that with training, employees develop leadership skills that enable them to inspire and engage the rest of the company. Morale improves despite a global workplace atmosphere of constant change and challenges. Leadership development programs allow executives to be promoted from within the organization, allowing for more seamless and less disruptive succession when current leaders retire or leave for other job opportunities.

$\operatorname{Mehta}(2011)^{(18)}$ study about situational leadership and personal effectiveness : profile of managerial functionaries in development organizations in India supported results of the present study and concluded that leadership being viewed as a behavioral that can be learned

Also Hersey (2012) (19) study about management of organization behavior: utilizing human resources, supported results of the present study through the underlying notion of situational leadership is that individuals can be trained to adjust their leadership styles depending on the situation, as well as the idea that leaders should treat different employees differently ,and the same employees differently depending on the situation.

Danborg(2011) $)^{(20)}$ study about the link between project management leadership and project, success supported results of the present study and summarized that the competencies for an effective leader are learned abilities.

Results revealed statistically significant improvement of nursing leaders level of knowledge on emotional intelligence and competencies post the educational program .This mean that the nursing leaders understand methods to control temper or get along with others. They know that their own and others emotional when makeup well can move people in directions that help accomplish intended goals and adapt to problem solving. Those nursing leaders became better equipped to use emotions to proactively redirect their attention to important events (e.g., face continuous work environment change)use emotions to enhance thought are through considering alternate perspectives, flexible planning, and creative problem solving . The findings of the present study is supported by Raza \& Kashif (2011) ${ }^{(21)}$ 
study about the impacts of emotional intelligence on leadership and team work .They found that emotional intelligence training can raise some sort of (self) awareness, which could change and/or develop one's individual perception of seeing and dealing with emotions.

Goleman (2008) ${ }^{(22)}$ study about best of HBR on emotionally intelligent leadership, support present study result and reported that the skills of emotional intelligence can be learned and growing own emotional intelligence takes practice and commitment. Also they insists that emotional intelligence can be measured, learned, and developed.

McKee et al (2008) (23) study for becoming a resonant leader supported the present study results and found that emotional intelligence can never be fully learned, but that there are several ways of building one's competences through training while emotional intelligence can never be fully developed, the training initially goes fast, and that the current or future leader must have the will to take on the training and be willing to develop it.

Adding Boyatzis (2007) ${ }^{(24)}$ study about developing emotional intelligence through coaching for leadership, professional and occupational excellence, found that one can, through coaching, develop emotional intelligence. Also Lopes, Cote and Salovey (2006) ${ }^{(25)}$ study on an ability: model of emotional intelligence: implications for assessment and training, supported the present study results and found that training can raise awareness about the importance of emotional skills and motivate people to learn.

Goleman et al. (2002) ${ }^{(26)}$ study about primal leadership supported the results of present study and found that emotional intelligence is learnable. Also results confirmed by Mayer\& Salovey (1993) ${ }^{\text {(27) }}$ study about the intelligence of emotional intelligence and found that emotional intelligence is an ability that can be developed and improved in the individuals for better results in the teams/groups. But Caruso et al.(2006) ${ }^{(28)}$ study on emotional intelligence in the workplace, not support present study results and they were not convinced that emotional intelligence actually can be taught, and training did not increase the emotional intelligence.

Results of present study revealed that the participative leadership style was the predominant one for nursing leaders and the selling leadership style was the second style for pre and pot program. The fact is that those nursing leaders were having high relationship and low task behavior that best suited for followers of moderate 
to high maturity. Those leaders does not make decision until problem is presented to their followers while their advice and suggestions are received .The decision is still the leader's but it is not taken until the staff are consulted . Participative leadership is for followers with competence but lack confidence or motivation ,they do not need much direction because of their skills, but need support to bolster their motivation.

The selling style as the scored predominant style indicates that leaders have high task and high relationship behavior, they make their own decisions, and announcing them to their followers and, tries to persuade them to accept it. Beside they accepts the possibility that their followers may resist the decision. The leaders in this case work well with follower with some competence, commitment, unable but willing and motivated. Nursing leaders with both selling and participating styles tend to do well working with followers with average levels of readiness, while would find it difficult to handle discipline problems and work groups with low levels of readiness . $\operatorname{Goleman}(\mathbf{2 0 0 8})^{(22)}$ study about best of harvard business review on emotionally intelligent leadership, supported results of the present study that the most effective executives use a collection of distinct leadership styles each in the right measure, at just the right time. Such flexibility is tough to put into action, but it pays off in performance. And better yet, it can be learned.

Also Larsson and Storhannus (2008) ${ }^{(29)}$ study about understanding leadership in successful non-profit organizations, support the results of present study and revealed that the majority of leaders thought that their most used leadership style was participating leadership style.

The participative leadership style is most appropriate to use when employees have fairly high competence and a variable commitment to achieve, while the managers perceive themselves to use supporting. The perception of what leadership style one uses could vary depending on the relationship with the employees. That is if the leader is a good friend of a subordinate, one can assume that the leader would use less harsh methods and letting the subordinate decide for him or herself instead of just telling them what to do and how to do it.

The present study results revealed statistically significant improvement of levels of leaders effectiveness on situational leadership post program from moderate to high level according to 
improvement of raters readiness level post program. The fact is that the improvement of nursing leaders levels of knowledge changed their level of leadership effectiveness .They understand that their is no one leadership style is most effective when nursing leaders are trying to influence followers, and that effective leaders are those who vary their leadership styles based on the readiness level of the follower and the situation.

This results are confirmed by Mehta (2011) ${ }^{(18)}$ who found that majority of respondents belong to the moderate effectiveness category confirmed the present study results leaders effectiveness level pre program. Also Bull(2010) ${ }^{(30)}$ who showed that majority of staff perceived their supervisors as having moderate effectiveness level followed by low effectiveness level.

As well as Larsson and Storhannus (2008) ${ }^{(29)}$ supported the results of pre program readiness levels and found that all leaders are on the moderate leaders effectiveness level .Beside Lay and Bruno (2006) ${ }^{(31)}$ study about personal values and leadership effectiveness supported the results of present study for leaders effectiveness levels pre program and found that majority of sample of executives has a moderate level of leadership effectiveness.

Readiness refers to the follower's experience, willingness and ability to take responsibility given a specific task. The level of maturity determines the appropriate combination of task and relationship behavior for the leader. The words maturity, readiness, willingness, and development are used alternatively to mean the same ${ }^{(32)}$. Effective leaders are those who vary their leadership styles based on the readiness level of the follower and the presenting situation. Effective leadership is determined by the ability of the leaders to assess the follower's readiness level and apply the appropriate leadership style to match the follower's readiness level ${ }^{(33) .}$

\section{Conclusion}

Pre program the level of majority of nursing leaders knowledge was moderate and low either for situational leadership, emotional intelligence competencies or effectiveness and adaptability based on situational leadership. They predominately use participating leadership style followed by secondary one selling style. Also most of nursing raters showed that their leaders were at low emotional intelligence competencies level and use participative 
leadership style .

After implementing of a well planed and organized educational program about situational leadership and emotional intelligence the nursing leaders showed improved leadership effectiveness. Apparently the situational leadership and emotional intelligence levels of nursing leaders improved so that contributed and improved their level of leadership effectiveness which indicated in the change in using participating leadership styles as predominant style for most of raters and improvement in their raters level of readiness.

\section{Recommendations}

- Prime importance establishing of learning center in every hospital for periodical improvement of knowledge and skills for nursing staff regarding situational leadership and emotional competencies which will increase their management awareness toward improving work performance.

- Train and increase nursing students awareness how to act nursing practices professionally using emotional intelligences competencies and using situational leadership theory

-Nursing leaders' attention to care for their nursing staff emotions.

\section{Further research are needed}

-Study other variables as financial performance, academic performance, clinical performance, and job satisfaction as variables for both emotional intelligence competencies and situational leadership styles .

\section{Refrences}

1- Nel P. ,Gerber P. ,Van D.,Haasbroek G.,Schultz H . and Werner A . Human Resource Management $\quad .6^{\text {th }}$ ed. CapTown,Oxford university press: 2004; 343

\section{2-Hughes, R., Ginnett, R., Curphy, G.} Leadership: enhancing the lessons of experience. $8^{\text {th }}$ ed. New York, McGraw-Hill/Irwin : 2015:346-386

3-Borowa A. and Darwish H. Business of Economics and Engineering, Field: International Marketing Identifyin Business Students'Leadership Styles, Marketing Master Program, Halmstad University, 2007 ;11

4-Lussier, R.N. and Achua, C.F.,Leadership, $2^{\text {nd }}$ ed. Portland, OR: South-Western, 2003;5.

5-Uma J. and Glenice W. The role of leadership theory in raising the profile of women in management. International Journal. 2006; 25 (4) : 236-250.

6-Middleton G.The Epistle To The Ephesians: Instilling Values Using 
Situational Leadership.Journal of Biblical Perspectives in Leadership.2006;1:28-48.

\section{7-Hersey P. Blanchard K. and Johnson}

D. Management of organizational behavior: Leading human resources 9 th ed. Englewood Cliffs, NJ: Prentice Hall,2007: 173-295

\section{8-Hersey P. , Blanchard K. and Johnson}

D. Leading for change: Combining vision with situational leadership. Management of organizational behavior. $9^{\text {th }}$ ed. Englewood Cliffs, NJ:Prentice-Hall,2008:814

\section{9-Golman D 1995 cited in Goleman D.} Emotional intelligence: Why it can matter more than IQ. $1^{\text {st }}$ ed., New York, NY: Random House: 2007;15

10-Golman 1995 cited in Goleman D., Boyzatzis, R. and McKee A. Primal leadership: Realizing the power of emotional intelligence. $3^{\text {rd }}$ ed., New York, Audio Renaissance, 2006:14$16,50-60$

11-Wolmarans S.2002 sited in Palme P., Jansen C. and Coetzee $M$. Perceptions of South African managers' emotional intelligence: a preliminary investigation. Southern Africa Business Review, 2006 ; 10 (1) :91-110
12- Blanchard, K.Leading at Higher Level:Blanchard on Leadership and Creating High performing Organization $.1^{\text {st }}$ ed., New Jersy Blanchard Management Corporation ,2010;75-90

13- Paul H. and Kenneth B. Management of Organizational Behavior: Utilizing Human Resources $.5^{\text {th }}$ ed.,PrenticHall,1988;474.

14- Léo F.C.B and Eduardo G.E.L . Personal Values And Leadership Effectiveness. E-Leader, Slovakia ,2006;1-9

15-Wolmarans I.S and Greeff A.,2001, 360-Degree Emotional Competency Profiler. Sighted in Hayward B.A. Relationship Between Employee Performance,Leadership And Emotional Intelligence In A south African Parastatal Organization . Master of Commerce, Rhodes University ,2005.

16-Palmer, P.N.\& Jansen, C.A. Emotional Intelligence as an Important Attribute of Transformational Leadership. Paper Presented at the Institute of Management Scientist Annual Conference, at the Southern African, Cape Town 2004; 17-29. 
17- Duggan A. Description of Leadership Effectiveness \& Adaptability .Avaliable at http://www.ehow. com/info_7758631

_description-leadership -effectiveness-

adaptability .html \#ixzz2MN49S4zx,

Demand Media Inc., 2013:1-3

18-Mehta W. Situational leadership and personal effectiveness :profile of managerial functions aries in development organizations in India. Working paper 225.IRMA faculty. Institute of Rural Management Anand. 2011

19-Hersey P. Management of Organizational Behavior: Utilizing HumanResources. $7^{\text {th }}$ Ed. USA .Pearson Education: 2012;70

20-Danborg T. The Link between Project Management Leadership and Project Success. Master Thesis. Blekinge Institute of Technology. School of Management. 2011;23

21- Raza A. and Kashif M. The impacts of Emotional Intelligence on Leadership and Team Work. Master thesis . Umeå School of Business. Umeå University. 2011;19

22-Goleman D. Best of HBR on Emotionally Intelligent Leadership. Harvard Business Review. 2nd Ed. 2008;15- 51
23- McKee, A., Boyatzis, R. \& Johnston, F. Becoming a Resonant Leader. $1^{\text {st }}$ ed.Boston, MA: Harvard Business Press. 2008;31

24-Boyatzis, R. Developing Emotional Intelligence Through Coaching for Leadership, Professional and Occupational Excellence. Westport, CT: Praeger Publishers. 2007; 155168.

25- Lopes P. Cote S. and Salovey P. 2006. An Ability: Model of Emotional Intelligence: Implications for Assessment and Training. In Druskat, V. , Sala F. and Mount G. Linking Emotional Intelligence and Performance at Work. $1^{\text {st }}$ ed. Mahwah, NJ: Lawrence Erlbaum Associates, Publishers.53-80.

26-Goleman D. Boyatzis R. and McKee A. Primal Leadership. $1^{\text {st }}$ ed. Boston, MA: Harvard Business School Press. $2002 ; 50$

27-Mayer J. and Salovey P. The intelligence of emotional intelligence, Intelligence, 1993; 17, 433-442

28-Caruso D. , Bienn B., and Kornacki S. 2006. Emotional Intelligence in the Workplace. $1^{\text {st }}$ ed. New York: Psychology Press.187-205 
29-Larsson L. and Storhannus $P$.

Understanding leadership in

Successful Non-Profit Organizations

A case-study of IKSU . Bachelor thesis. Management som inriktning på handelshögskolan. Umeå University. 2008;20

30-Bull D. Situational Leadership Style and Employee Turnover Intent :Acritical Examination of Health Care Organizations . Doctoral Thesis. School of Public Service Leadership .Capella University. 2010;23

31-Lay E. and BrunoL. Personal Values and Leadership Effectiveness. ELeader, Slovakia. 2006; 1 of 9.Available at http://www.g-casa.com/ download/ Bruno_ Pers onal_Values_Leadership.pdf

32-Arvidsson M., Johansson C., Ek, A., and Akselsson R. Situational Leadership in Air Traffic Control.2007; Journal of Air Transportation,12(1), 67-86.

33-Gayle M. Relationship Between Employee Perceptions of Leadership Styles and Job Satisfaction in A Commercial Clinical Laboratory Environment. Doctoral Thesis. Wayne Huizenga School of Business and Entrepreneurship. Nova Southeastern University. 2009;33 